\title{
Pemberdayaan Masyarakat Melalui Pengelolaan Sampah Menjadi Nilai Ekonomis dan Pembentukan Bank Sampah di Desa Pentadu Timur Kecamatan Tilamuta Kabupaten Boalemo
}

\author{
Sri Indriyani S Dai dan Srie Isnawaty Pakaya \\ Universitas Negeri Gorontalo \\ E-mail : indriyanidaiseme24@gmail.com \\ DOI: https://doi.org/10.21107/pangabdhi.v5i2.6113
}

Artikel Diterima : 12 Agustus 2019/ Revisi : 7 September 2019/Terbit : 19 Oktober 2019

\begin{abstract}
Abstrak
Pemerintah Kabupaten Boalemo selalu memiliki cara untuk mengedukasi masyarakatnya agar sadar akan lingkungan yang bersih. Untuk menjaga dan melestarikan lingkungan yang bersih dan sehat salah satunya dengan menyiapkan tempat pengolahan sampah yang bisa dimanfaatkan dan memiliki nilai ekonomi bagi masyarakat. Saat ini terdapat dua belas desa yang ada di Kabupaten Boalemo yang termasuk pada zona 1 yang merupakan area pengolahan sampah yang merupakan kawasan bisnis yang akan diatasi dengan sistem langsung dalam jangka pendek. Salah satu diantaranya adalah Desa Pentadu Timur yang berada di Kecamatan Tilamuta. Dalam pencapaian tujuan tersebut metode yang dipakai adalah 1) Sosialisasi dan pelatihan pengelolaan sampah menjadi bahan/ barang bernilai ekonomis dan pembentukan bank sampah 2) Sosialisasi Pengelolaan Sampah dan Pembentukan Bank Sampah di Sekolah-Sekolah Di Desa Pentadu Timur 3) Pembentukan Bank Sampah 4) Pembuatan Tempat Sampah 5) Pemasaran Produk yang dihasilkan melalui program pengabdian pada masyarakat. Pelaksanaan program KKN-Pengabdian dapat membantu masyarakat dalam hal ini di desa Pentadu Timur Kecamatan Tilamuta Kabupaten Boalemo untuk mengatasi persoalan sampah, menumbuhkembangkan dan meningkatkan kesadaran masyarakat dalam penanganan sampah serta meningkatkan nilai ekonomis sampah untuk peningkatan kesejahteraan masyarakat.
\end{abstract}

Kata Kunci: kesadaran masyarakat, kesejahteraan masyarakat, sampah

\section{PENDAHULUAN}

Pemerintah Kabupaten Boalemo selalu memiliki cara untuk mengedukasi masyarakatnya agar sadar akan lingkungan yang bersih. Untuk menjaga dan melestarikan lingkungan yang bersih dan sehat salah satunya dengan menyiapkan tempat pengolahan sampah yang bisa dimanfaatkan dan memiliki nilai ekonomi bagi masyarakat.

Untuk mengatasi persoalan sampah, perlu dilakukan perubahan paradigma yang memandang sampah sebagai sumber daya yang memiliki nilai ekonomis dan dapat dimanfaatkan. Yang semula hanya sekedar mengumpulkan, mengangkut dan membuang sampah ke TPA berganti menjadi pengelolaan sampah dengan menerapkan 3 R (Reduce, Reuse, Recycle). Saat ini terdapat dua belas desa yang ada di Kabupaten Boalemo yang termasuk pada zona 1 yang merupakan area pengolahan sampah yang merupakan kawasan bisnis yang akan diatasi dengan sistem langsung dalam jangka pendek. Salah satu diantaranya adalah Desa Pentadu Timur yang berada di Kecamatan Tilamuta.
Penyelesaian masalah ini difokuskan pada upaya bagaimana sampah yang ada dapat dikelola dengan baik, sehingga anggaran pemerintah daerah ditujukan untuk mengelola sampah dengan dibangunnya Tempat Pengelolaan Sampah 3 R di Desa Pentadu Timur yang merupakan wujud upaya sosialisasi pemerintah dalam hal bebas sampah untuk terciptanya daerah sehat.

Pengurangan sampah sudah dimulai dari masyarakat itu sendiri, yaitu dengan membudayakan membuang sampah pada tempatnya dan memisahkan sampah kering dan basah sehingga dapat di daur ulang dan bisa dimanfaatkan sehingga memiliki nilai ekonomi bagi masyarakat. Program ini sudah disosialisasikan kepada masyarakat oleh Dinas Lingkungan Hidup Dan Kehutanan Kabupaten Boalemo. Namun belum terlihat perubahan yang signifikan dalam mengatasi permasalahan sampah.

Dalam pencapaian tujuan tersebut metode yang dipakai adalah 1) Sosialisasi dan pelatihan pengelolaan sampah menjadi bahan/ barang 
bernilai ekonomis dan pembentukan bank sampah 2) Sosialisasi Pengelolaan Sampah dan Pembentukan Bank Sampah di Sekolah-Sekolah Di Desa Pentadu Timur 3) Pembentukan Bank Sampah 4) Pembuatan Tempat Sampah 5) Pemasaran Produk yang dihasilkan melalui program pengabdian pada masyarakat. Pelaksanaan program KKN-Pengabdian dapat membantu masyarakat dalam hal ini di desa Pentadu Timur Kecamatan Tilamuta Kabupaten Boalemo untuk mengatasi persoalan sampah, menumbuhkembangkan dan meningkatkan kesadaran masyarakat dalam penanganan sampah serta meningkatkan nilai ekonomis sampah untuk peningkatan perekonomian masyarakat.

\section{METODE}

Kegiatan ini dilakukan dengan metode sosialisasi dan pelatihan praktek langsung serta pendampingan pengelolaan sampah menjadi barang kerajinan yang bernilai ekonomis. Kegiatan-kegiatan ini mencakup teori dan praktek yang meliputi: (1) Sosialisasi; (2) Pengenalan produk; dan (3) Pembuatan produk (praktek langsung). Sosialisasi dan pelatihan dilaksanakan dalam rangka Memperkenalkan ilmu pengetahuan dan teknologi pengolahan sampah menjadi barang/ bahan yang bernilai ekonomis untuk mengatasi permasalahan yang timbul akibat tidak terkelolanya sampah di Desa Pentadu Timur serta untuk meningkatkan kesadaran warga masyarakat terhadap sampah, sehingga mereka terlibat secara langsung dalam menangani sampah yang ada di Desa Pentadu Timur. Memperkenalkan teknologi pemasaran on line dalam memasarkan barang/ bahan yang dihasilkan.

\section{HASIL DAN PEMBAHASAN}

Berdasarkan identifikasi permasalahan maka dirumuskan program inti dalam pelaksanaan kegiatan ini adalah pelaksanaan sosialisasi, pelatihan, pendampingan dan praktek langsung bagi KSM Bulalo Jaya dan ibu-ibu rumah tangga di Desa Pentadu Timur guna meningkatkan pemahaman dan pengetahuan masyarakat dalam mengelola sampah menjadi nilai ekonomis dan pembentukan bank sampah di Desa Pentadu Timur Kacamatan Tilamuta Kabupaten Bualemo.

\section{Sosialisasi dan Pelatihan Pengelolaan Sampah}

Pelaksanaan sosialisasi dan pelatihan ini bertempat di Aula Kantor Desa Pentadu Timur Kecamatan Tilamuta Kabupaten Gorontalo.
Kegiatan ini dilakukan dengan menyampaikan materi, demonstrasi dan praktek langsung. Kegiatan ini dibuka langsung oleh Bapak Kepala Desa Pentadu Timur Kecamatan Tilamuta Kabupaten Gorontalo yang dihadiri oleh Kelompok Swadaya Masyarakat (KSM Bulalo Jaya) dan ibu-ibu rumah tangga pengelola sampah di Desa Pentadu Timur Kecamatan Tilamuta Kabupaten Boalemo.

Kegiatan sosialisasi dan pelatihan ini dimulai dengan pemaparan materi oleh Nursiah Hasjim selaku pemateri dari Badan Penaggulangan Bencana Daerah Kabupaten Bualemo yang memaparkan materi mengenai Sistem Bank Sampah.

Sesi berikutnya pemaparan materi oleh Sri Indriyani S. Dai selaku pelaksana program KKS Pengabdian yang memaparkan materi mengenai Potensi Ekonomi Melalui Pengelolaan Sampah Menjadi Nilai Ekonomis, selanjutnya pemaparan materi oleh Srie Isnawati Pakaya, S. Pd, M.Si yang memaparkan materi tentang Manajemen Bank Sampah Dalam Upaya Meningkatkan Keterampilan Masyarakat, selanjutnya pemaparan materi oleh Lanto Miriatin Amali, S. Sos, M. Si yang memaparkan materi tentang Perhitungan Harga Pokok Produksi Kerajinan Berbahan Baku Sampah Plastik Dan Botol Kaca, selanjutnya pemaparan materi oleh Umin Kango, S. Pd, M. Si yang memaparkan materi tentang Strategi Pemasaran Produk Kerajinan Berbahan Baku Sampah Plastik Dan Botol Kaca.

Selanjutanya pemaparan materi sekaligus pelatihan oleh Yulinda L. Ismail, S. Pd, M. Si mengenai Pengelolaan Sampah Plastik Menjadi Produk Kerajinan Yang Bernilai Ekonomis dilanjutkan dengan praktek langsung. Produk kerajinan yang dihasilkan dari sampah plastik yaitu berupa vas bunga, bunga dan bunga. Mahasiswa bersama para peserta pelatihan mempraktekan langsung bagaimana membuaat produk kerajinan yang berbahan baku sampah plastik. Guna menghasilkan produk kerajinan dengan kualitas yang baik, ada beberapa hal yang harus diperhatikan terutama dalam hal pemilihan bahan baku, pengolahan bahan baku sampai dengan tahapan proses pembuatan.

Tahapan pembuatan vas bunga menggunakan bahan baku botol plastik bekas yang sudah dicuci bersih dan dikeringkan, potong botol coca cola bekas hingga menjadi dua bagian, semprotkan cat berwarna putih kekedua bagian potongan botol plastic secara merata, selanjutnya tempelkan manic manic atau pita sesuai selera dengan menggunakan lem plastik, ambil piringan 
CD bekas rekatkan pada botol bagian atas dengan menggunakan lem. Piringan CD bekas ini berfungsi untuk menopang vas bunga dari botol plastik. Bahan yang dibutuhkan:

- Botol plastik bekas ukuran 1,5 liter

- Cutter

- Gunting

- Cat semprot berwarna putih

- Manik-manik/pita

- Lem plastik

- Lem tembak

- Piringan CD bekas

Tahapan pembuatan bunga dari plastik bekas, pilih tas plastik bekas yang masih layak, guntinglah sedikit bagian atas dan bagian bawah plastik, lipat menjadi 4 bagian lalu gunting garis lipatan, gabungla ke empat potongan plastik menjadi 1, lipatlah seperti sedang membuat kipas dari kertas, ikatlah oplastik tersebut dengan menggunakan kawat atau dijahit dengan benang, bukalah tiap lapisan plastic agar terlihat seperti bunga yang mekar. Tambahkan daun dibagian batang bunga.

Bahan yang dibutuhkan:

- Plastik kresek bekas (warna sesuai keinginan)

- Gunting

- Jarum

- Benamg
- Kawat

- Lem tembak

- Daun palsu

Selanjutanya pemaparan materi sekaligus pelatihan oleh Nurhayati Panigoro, S. Pd, M. Si mengenai Pengelolaan Sampah Kaca Menjadi Produk Kerajinan Yang Bernilai Ekonomis dilanjutkan dengan praktek langsung.

Tahapan pembuatan kerajinan menggunakan bahan baku botol kaca bekas yang sudah dicuci bersih dan dikeringkan, sediakan beberapa wadah untuk proses pengecatan botol (jumlah wadah disesuaikan dengan varian warna yang diinginkan), keringkan cat dengan cara dijemur sedikit dan diangin-anginkan, setelah kering mulailah berkreasi dengan mengunakan stiker, manik-manik atau pita dengan menggunakan lem.

Bahan yang dibutuhkan:

- Botol kaca bekas bekas

- Wadah untuk cat

- Cat

- Gunting

- Manik-manik

- Pita

- Lem tembak

- Lem

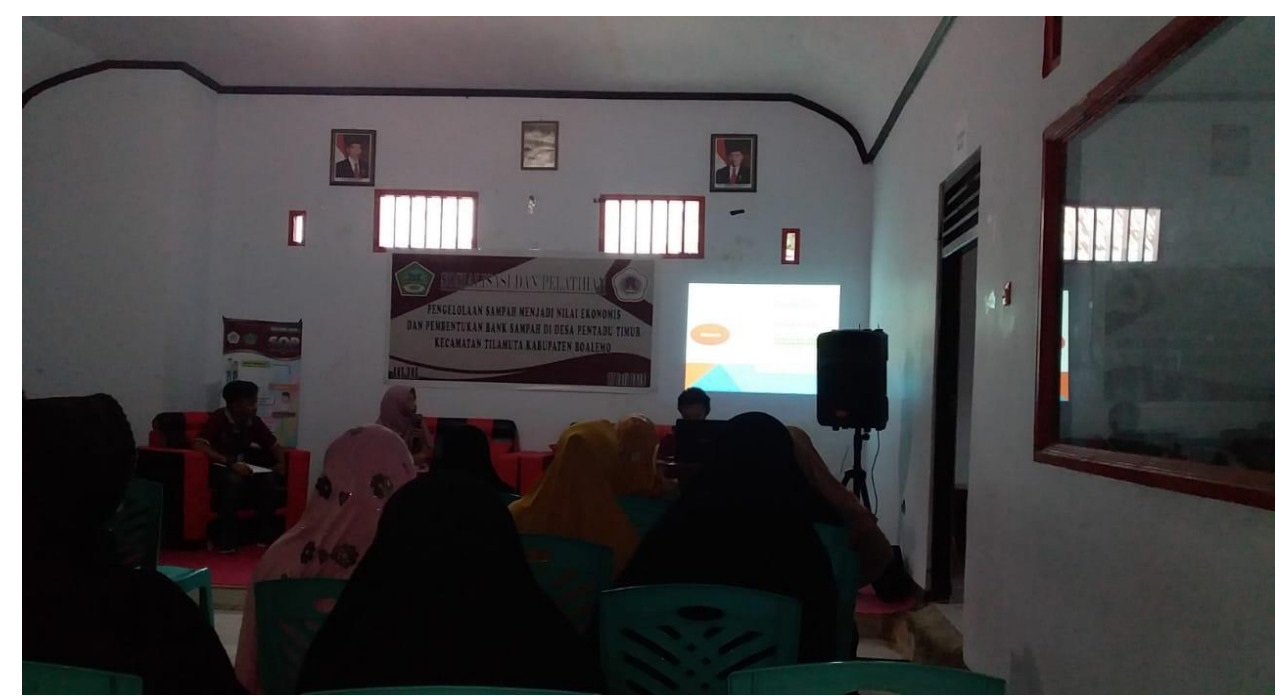

Gambar 1. Sosialisasi Pengelolaan Sampah 


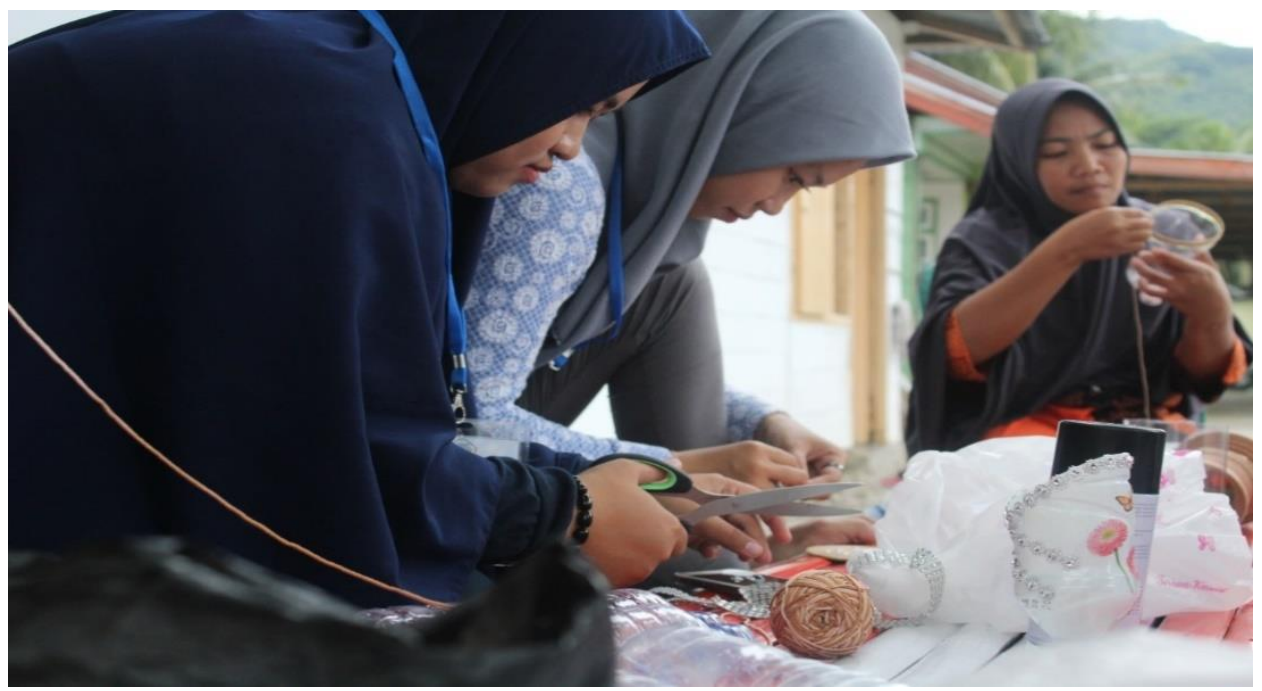

Gambar 2. Proses Pembuatan Vas Bunga dan Bunga

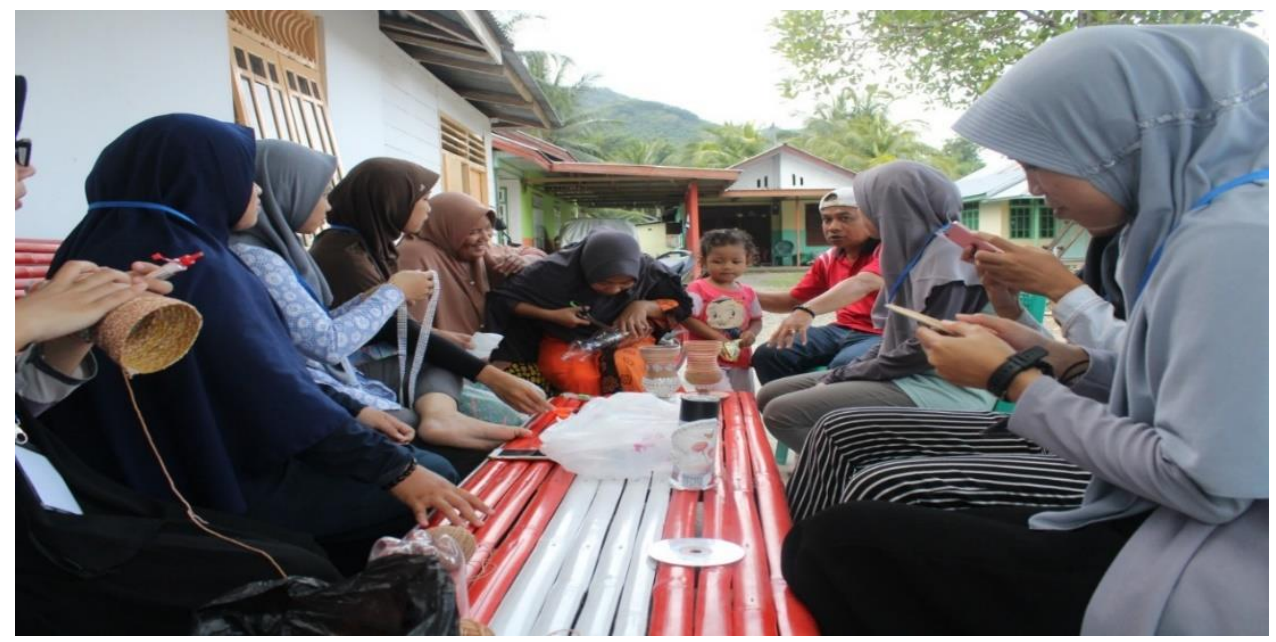

Gambar 3. Proses Pembuatan Vas Bunga dan Bunga

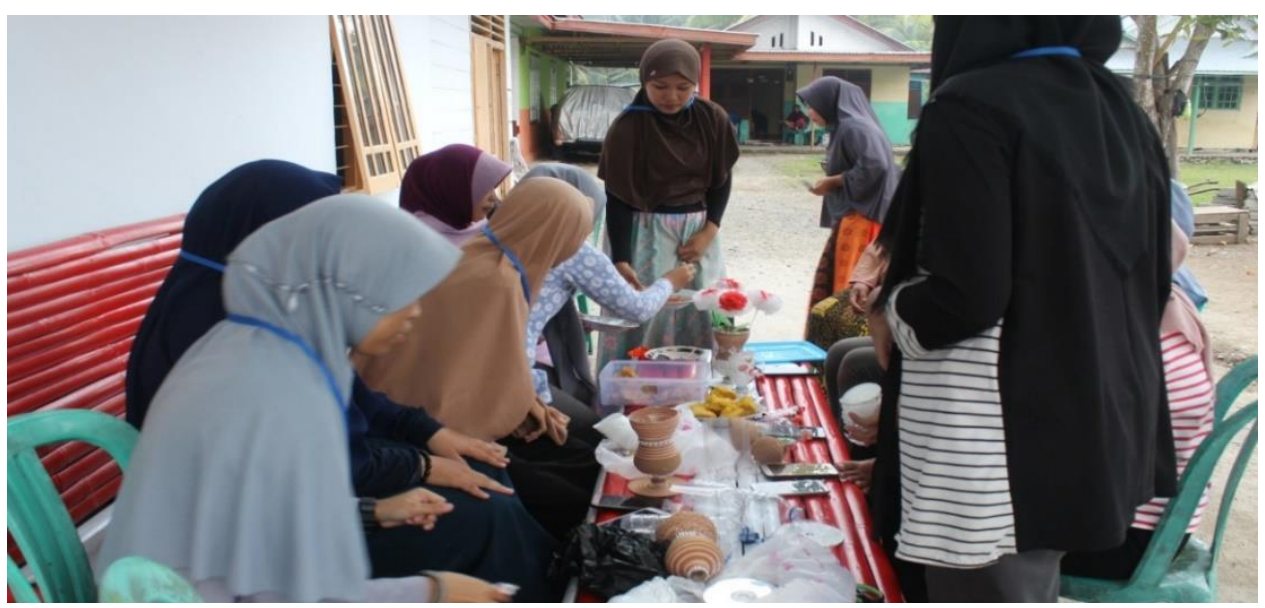

Gambar 4. Proses Pembuatan Vas Bunga dan Bunga 


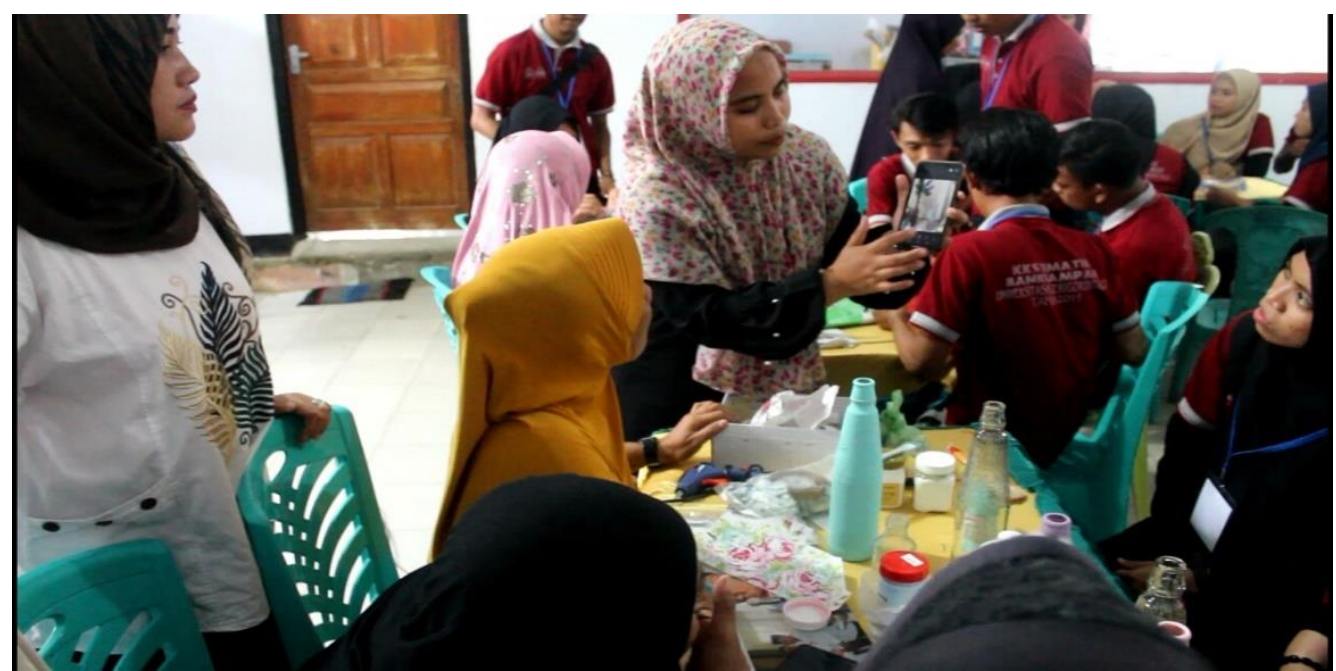

Gambar 5. Proses Pembuatan Kerajinan dari Botol Kaca

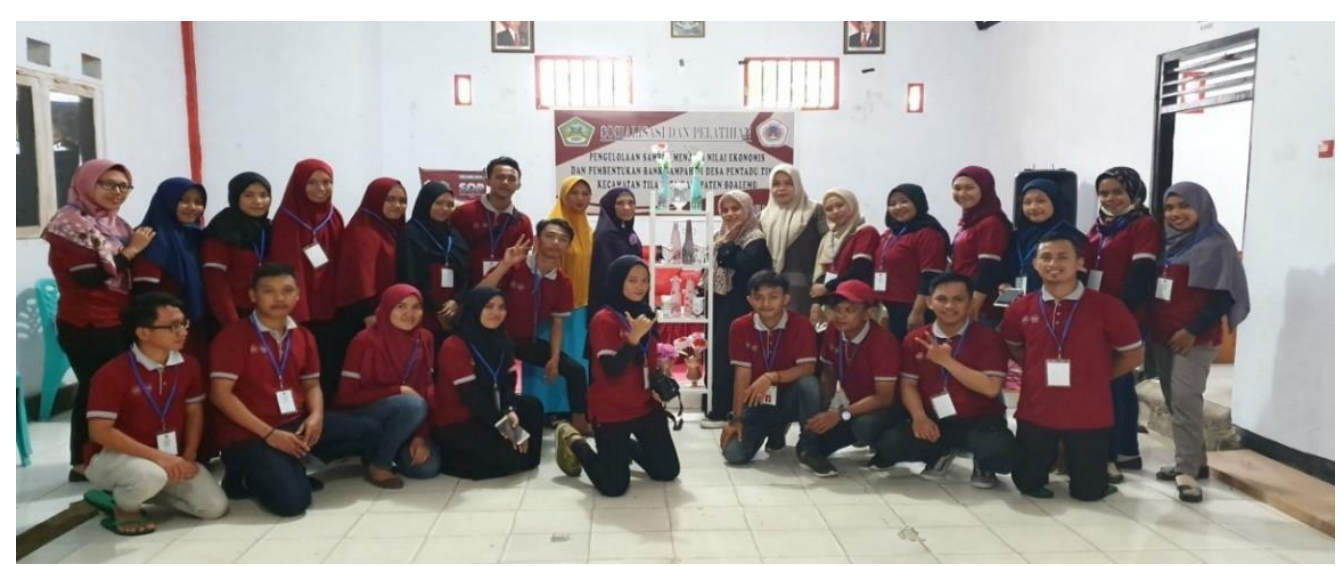

Gambar 6. Kerajinan yang dihasilkan

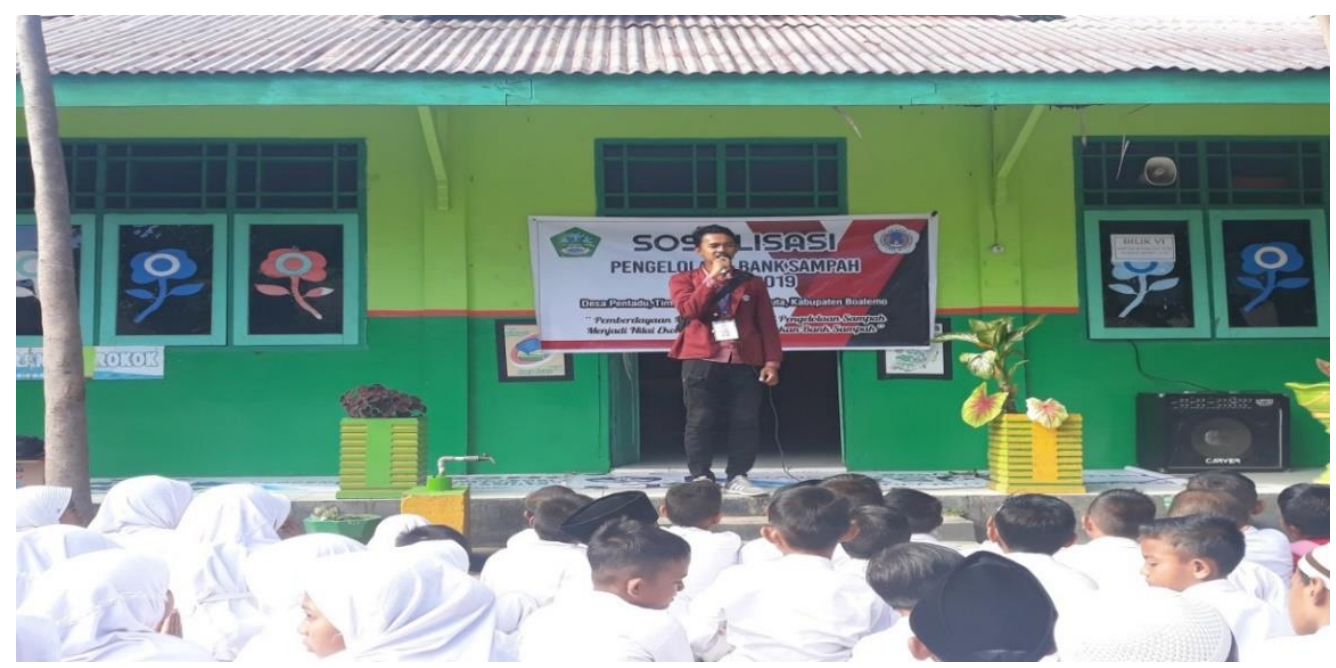

Gambar 7. Sosialisasi Pengelolaan Sampah dan Pembentukan Bank Sampah Di Sekolah-sekolah di Desa Pentadu Timur 


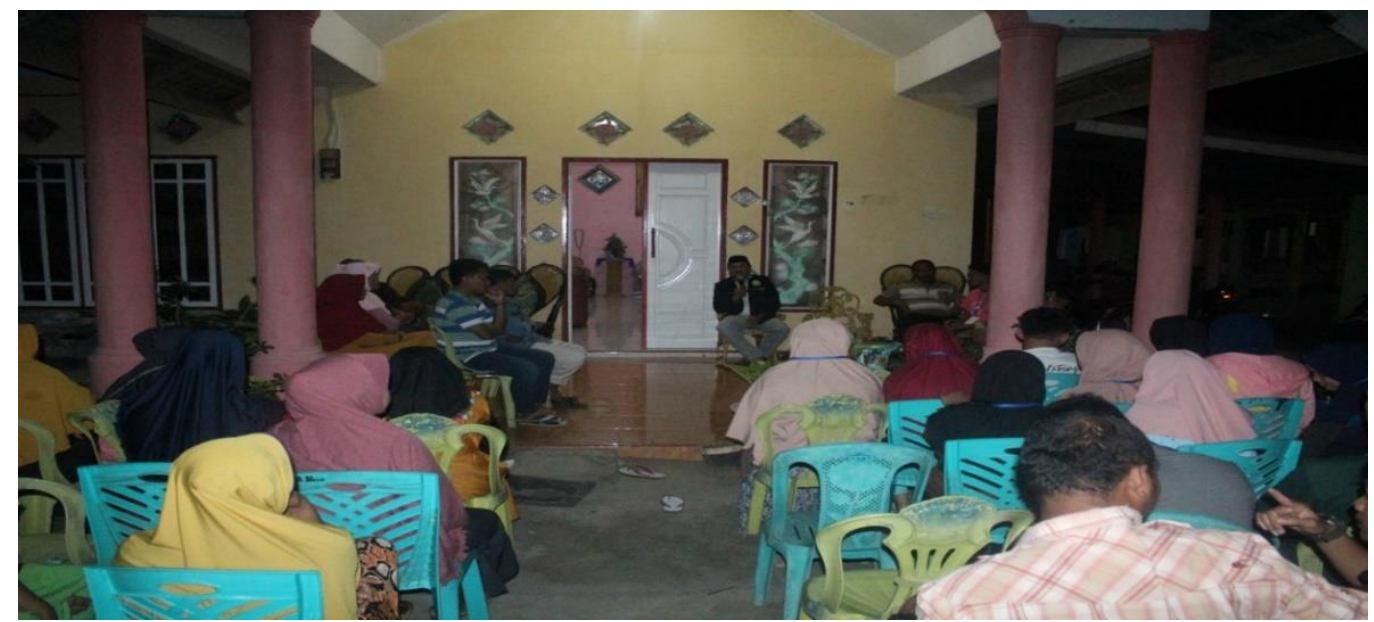

Gambar 8. Pembentukan Bank Sampah

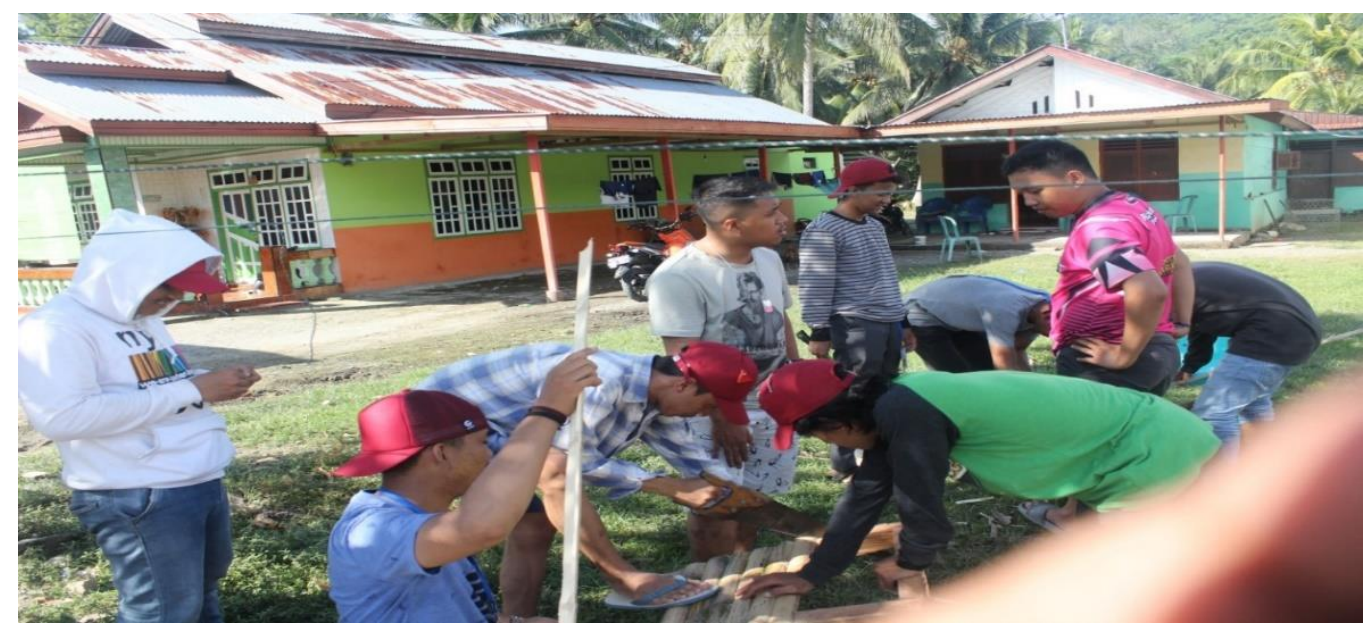

Gambar 9. Proses Pembuatan Tempat Sampah

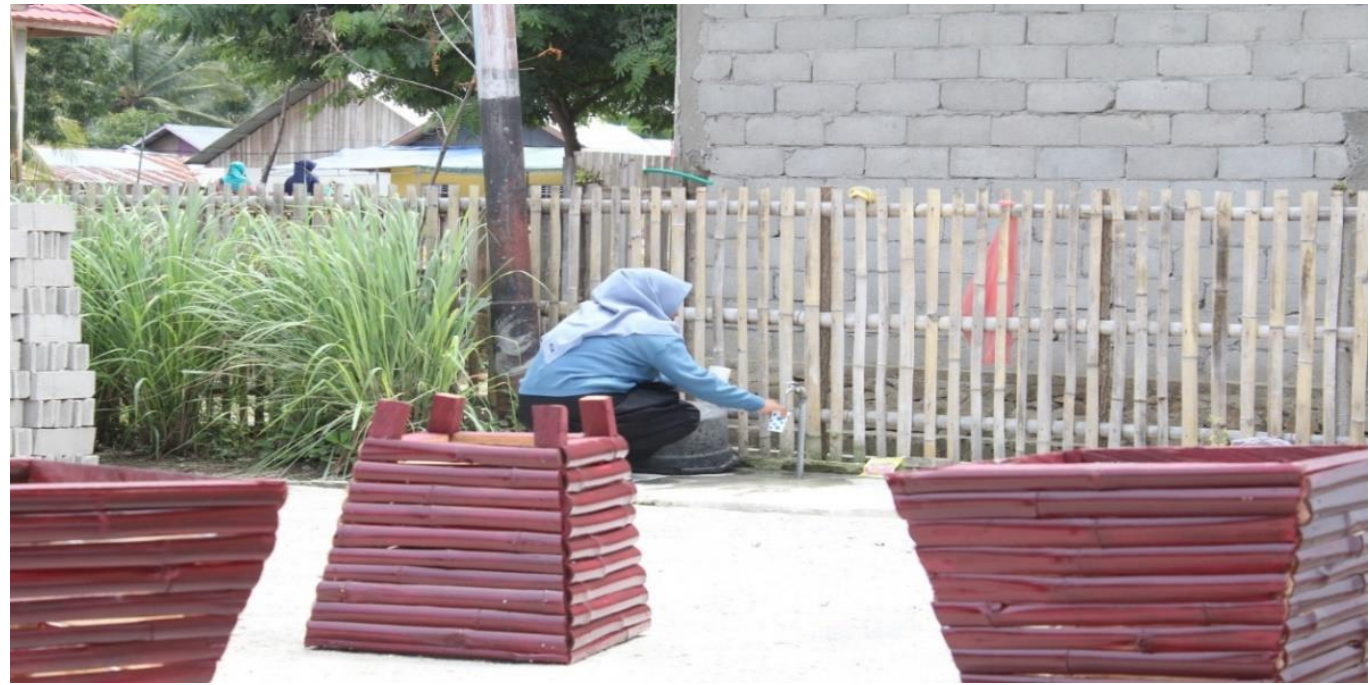

Gambar 10. Proses Pembuatan Tempat Sampah

Sosialisasi Pengelolaan Sampah dan yang dilaksanakan oleh mahasiswa KKS. Pembentukan Bank Sampah di Sekolah- Kegiatan ini bertujuan untuk meningkatkan Sekolah Di Desa Pentadu Timur kesadaran warga masyarakat terhadap sampah,

Kegiatan ini dilakukan dilaksanakan di sehingga mereka terlibat secara langsung dalam sekolah-sekolah yang ada di Desa Pentadu Timur menangani sampah yang ada di Desa Pentadu 
Timur serta mengurangi volume sampah dan agar warga sekolah dapat menempatkan sampah pada tempatnya serta dapat mengelola sampah menjadi produk yang bernilai ekonomis serta pihak sekolah dapat membentuk bank sampah.

\section{Pembentukan Bank Sampah}

Penyelesaian masalah sampah tidak hanya dilakukan dengan mengandalkan petugas kebersihan saja. Seluruh lapisan masyarakat harus membantu pemerintah untuk bergerak bersama dalam menangani masalah sampahdengan penerapan system $3 \mathrm{R}$ (reduce, reuse, recycle) dalam wujud bank sampahdi Desa Pentadu Timur. Sistem ini berguna untuk mengelola sampah dengan menampung, memilah, dan mendistribusikan sampah kefasilitas pengolahan sampah dalam hal ini ke TPS 3 R di Desa Pentadu Timur. Sehingga sampah di tempat pembuangan akhir bisa berkurang bahkan bisa bernilai ekonomis.

Untuk pengelolaannya sudah ditetapkan beberapa orang sebagai petugas dan pengelola bank sampah yag bertanggung jawab dalam pengoperasiannya dalam hal ini KSM Bulalo Jaya yang telah dibuatkan surat keputusan pada tahun 2018 oleh Kepala Desa. Adapun administrasi kelengkapan yang harus dimiliki oleh bank sampah adalah sebagai berikut:

1. Buku tabungan untuk anggota

2. Buku daftar anggota

3. Buku induk besar keuangan bank sampah

4. Buku rekap penyetoran anggota

5. Daftar hadir anggota yang menyetorkan sampah

Pada prakteknya susunan pengurus pengelola bank sampah yang telah ditetapkan mnerupakan pengelola TPS 3 R yang dilaksanakan oleh KSM Bulalo Jaya adalah sebagai berikut:

Ketua : Hj. Mintje Pomalango

Sekertaris : Asra Umar

Bendahara : Santi Abubakar

Seksi Administrasi Dan Pencatatan: Femi Lagili

Seksi Pengawasan: Udin Ibrahim

Seksi penyuluhan: Nurhayati Latif

Seksi Pemasaran: Nunce Pomalango

Seksi penimbangan Dan pengepakan: Tirna Bantu

Dalam kegiatan ini mahasiswa KKS berperan untuk memberikan pembelajaran dan praktek administrasi dan keuangan dalam pengelolaan bank sampah. Pembuatan tempat sampah dengan memanfaatkan bahan yang sudah ada danmudah didapat serta ramah lingkungan. Bentuk kegiatan ini adalah membuatkan bak sampah yang ditempatkan secara strategis agar mudah dijangkau oleh seluruh masyarakat, serta memberikan penyuluhan akan pentingnya menjaga kesehatan di lingkungan Desa Pentadu Timur. Tujuan dari kegiatan ini adalah :

a. Meningkatkan pengetahuan kepada masyarakat Desa Pentadu Timur akan dampak negatif dan bahayanya dari sampah terhadap kesehatan.

b. Meningkatkan kesadaran masyarakat Desa Pentadu Timur untuk tidak membuang sampah sembarangan.

c. Meningkatkan rasa kepedulian lingkungan dan kesehatan terhadap perilaku pembuangan sampah.

d. Mengoptimalkan kesadaran untuk membuang sampah pada tempat sampah yang sudah disediakan.

Bahan yang dibutuhkan:

- Kayu

- Bambu

- Paku Kecil

- Palu

- Gergaji

- Meteran

- Pensil

- Cat

- Kuas

\section{Pemasaran Produk yang dihasilkan}

Untuk memperkenalkan dan menarik perhatian pelanggan produk kerajinan yang dihasilkan kepada masyarakat selaku konsumen, mahasiswa KKS berupaya untuk memperkenalkan produk kerajinan dengan cara memasarkan secara on line, lewat media social Facebook, Shopee, Instagram, WhatsApp, dll.

\section{Pendampingan dan Evaluasi Program}

Proses pendampingan dan evaluasi program pada kelompok swadaya masyarakat Bulalo Jaya dan masyarakat dilakukan secara bersamaan. Hal ini dilakukan setiap kali kunjungan oleh tim dengan melakukan analisis terhadap output yang dihasilkan, baik produk maupun kegiatankegiatan yang telah dilakukan mahasiswa beserta masyarakat dalam hal ini adalah pengelola sampah. Evaluasi juga dilakukan pada kontribusi bantuan peralatan dan bahan-bahan pengolahan dalam mendukung kelancaran 


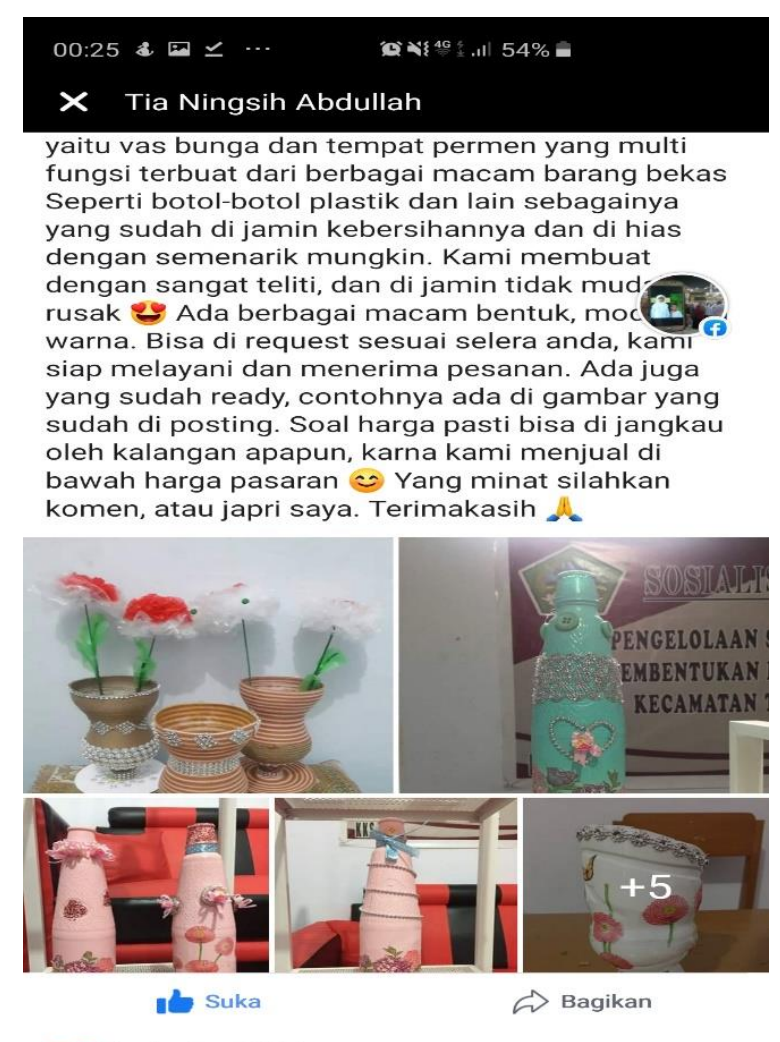

00 Anda dan 59 lainnya III

Gambar 11. Pemasaran on line melalui FB

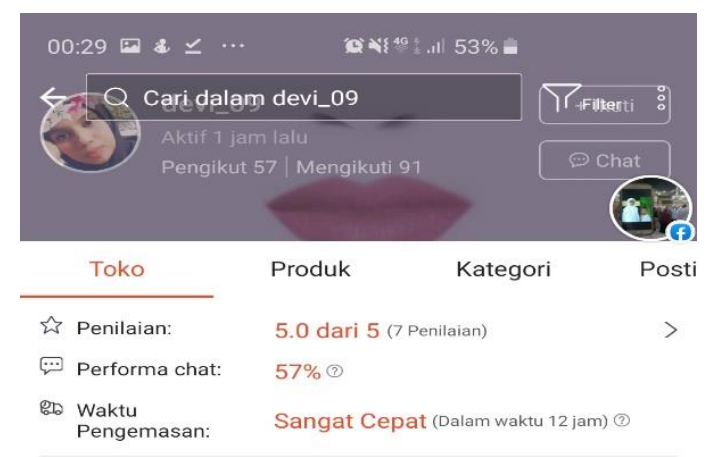

KKS UNG 2019 DS. PENTADU TIMUR

Tautan Toko: shopee.co.id/devi_09 Akun Terverifikasi $\square ⓕ$

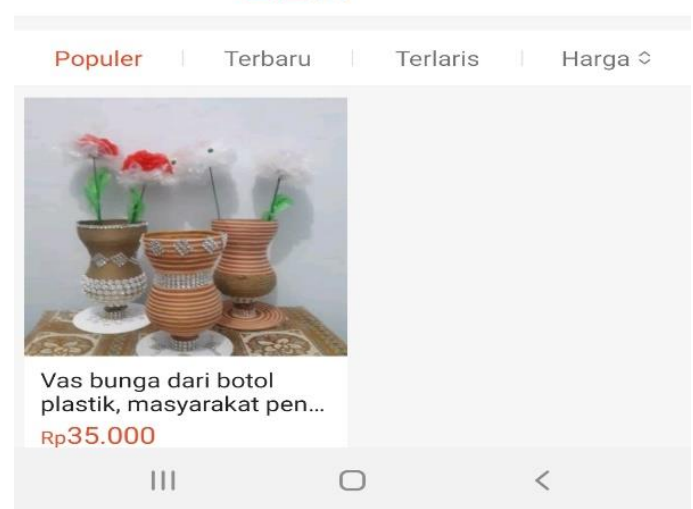

Gambar 12. Pemasaran on line melalui Shopee proses produksi kerajinan berbahan baku sampah dan proses pemasaran produk tersebut guna meningkatkan taraf hidup masyarakat di Desa Pentadu Timur Kecamatan Tilamuta Kabupaten Boalemo. Evaluasi secara khusus juga dilakukan oleh pihak Lembaga Penelitian dan Pengabdian Masyarakat (LPPM) Universitas Negeri Gorontalo terkait keberhasilan program yang dilaksanakan oleh tim KKN Pengabdian.

Program pelaksanaan KKS Pengabdian yang dilakukan oleh Lembaga Penelitian Dan Pengabdian Masyarakat Universitas Negeri Gorontalo dengan tema Bank Sampah merupakan kegiatan pemberdayaan kepada masyarakat yang akan melahirkan mahasiswa yang memiliki empati dan peduli terhadap permasalahan masyarakat ekonomi lemah dan mampu memberdayakan mereka untuk menolong diri mereka sendiri sehingga memiliki taraf hidup yang lebih baik.

Pelaksanaan KKN Pengabdian yang telah dilakukan selama ini sangat bermanfaat dalam peningkatan perekonomian masyarakat di Desa Pentadu Timur secara khusus dan masyarakat Kecamatan Tilamuta pada umumnya, yang dilakukan melalui program-program yang telah diberikan kepada masyarakat terutama pada program bank sampah. Namun setelah dilakukan pemberdayaan melalui sosialisasi, pelatihan dan pendampingan pengolahan sampah dan juga pembentukan Bank Sampah. Hal ini dilakukan agar sampah yang ada di Desa Pentadu Timur menjadi bermanfaat dan memiliki nilai ekonomis. Pemaparan penjelasan yang telah dilakukan diantaranya penjelasan pemilahan sampah yang masih bermanfaat dengan sistem 3 $\mathrm{R}$, pengelolaan sampah menjadi nilai ekonomis dan juga proses pembentukan Bank Sampah. Sosialisasi ini juga di sertai dengan informasi pemasaran apabila barang daur ulang seperti sampah dimanfaatkan sebagai barang kerajinan melalui media. Pengabdian masyarakat mengenai pemberdayaan masyarakat melalui pengelolaan sampah menjadi nilai ekonomis dan pembentukan bank sampah di Desa Pentadu Timur telah selesai dilaksanakan. Diharapkan dengan adanya kegiatan ini masyarakat mengetahui adanya Bank Sampah dapat membantu perekonomian masyrakat itu sendiri. Setelah terbentuknya Bank Sampah diharapkan kedepannya masyarakat dapat mengolah sampah menjadi barang berharga atau daur ulang sampah. Kemudian tim KKS Pengabdian masyarakat membantu mengenalkan administrasi dan keuangan serta pemasaran melalui media 
sosial atau internet sehingga produk yang mereka buat dari daur ulang sampah bisa dipasarkan melalui media online.

\section{KESIMPULAN}

Berdasarkan hasil dan pembahasan diatas dapat disimpulkan bahwa kegiatan ini berlangsung dengan baik sesuai dengan yang direncanakan. Mitra antusias dan berpartisifasi aktif dalam melaksanakan kegiatan. Kegiatankegiatan yang telah dilakukan, antara lain:

1). Sosialisasi dan pelatihan pengelolaan sampah menjadi bahan/ barang bernilai ekonomis dan pembentukan bank sampah

2) Sosialisasi Pengelolaan Sampah dan Pembentukan Bank Sampah di SekolahSekolah Di Desa Pentadu Timur

3) Pembentukan Bank Sampah

4) Pembuatan Tempat Sampah

5) Pemasaran Produk yang dihasilkan Permasalahan sampah hingga saat ini masih menjadi persolaan yang rumit, bahkan akan tetap menjadi persoalan serius. Oleh karenanya, disarankan kepada pihak terkait (masyarakat, aparat operangkat desa maupun pemerintah daerah) untuk terus secara berkesinambungan dan terpadu untuk memerangi masalah sampah.

\section{DAFTAR PUSTAKA}

Aneka Barang Kerajinan Dari Limbah Plastik https://www.google.com/search?q=aneka+ barang+kerajinan, diakses Juni 2019.

Badan Pusat Statistik, 2018. Kecamatan Tilamuta Dalam Angka 2018. Badan Pusat Statistik Kabupaten Boalemo.

Utami, Eka, 2013. Buku Panduan Sistem Bank Sampah Dan 10 Kisah Sukses. Jakarta: Yayasan Unilever Indonesia 